\title{
9 \\ Rights-Based Practice and Marginalized Children in Child Protection Work
}

\author{
Bente Heggem Kojan and Graham Clifford
}

\section{Marginalization: An Integral Part of the Picture in Child Protection}

Marginalization is unavoidable in societies where exchange, distribution and accumulation of goods and services predominantly take place in the market. It follows from this that marginalization as such is not something that agencies and services can avoid, though they can seek to mitigate its negative effects in a variety of ways. When those outside the market are dependent on assistance of different kinds from several agencies, they will be especially vulnerable. The services will themselves, though not necessarily in any deliberate way, be agents of marginalization; they contribute to its often subtle and complex dynamics (Pusic 1972). Marginalization in the perspective Pusic provided is in part a product of services and provisions at the margins of the market that impose criteria and tests for providing help, or even penalties that may incur loss of status or integrity

B. H. Kojan $(\bowtie) \bullet$ G. Clifford NTNU, Trondheim, Norway e-mail: bente.h.kojan@ntnu.no 
for those who are helped. The economic costs involved are largely met by the state or its agents in an advanced welfare society such as those in Scandinavia. The moral costs fall upon the users of services.

Marginalization affects family life. Families in contact with child protection often have severely deficient social and helping networks and dysfunctional family relations. These tend to be associated with social isolation or poor social integration, not only for parents, but also for their children. To what extent might the implementation of CRC lead to better welfare for children and families who suffer most in terms of marginalization? This is an under-researched question, and important to investigate since it is a characteristic of child protection systems that social inequality as a marginalization generator and child protection intervention rates correlate significantly (Bywaters et al. 2015; Clifford et al. 2015; Kojan 2011). This does not necessarily mean that those with the greatest needs get most help. On the contrary, the least marginalized families seem to be the ones receiving most help (Clifford et al. 2015). Several findings from recent Norwegian research strongly suggest that reform and refocusing have not been sufficiently successful (Clifford et al. 2015; Hennum 2017). This can be naively interpreted as a 'failure' of the services. A more interesting approach is to examine how child protection and other services deal with the normative complexity and ambiguities that attend upon services for children. Welfare services do not operate only on the basis of legal rules and principles. They are embedded in the mores of a society that expects that families adopt childrearing and socialization practices that meet the needs of the knowledge economy.

\subsection{Marginalization in Egalitarian Societies}

Norwegian Child Protection, as well as that in other Scandinavian countries, has been, at least partly, focused on equality as a goal in an egalitarian social system (Kojan 2011). In England and other Anglophone countries, equality is not really a goal of child protection and the social solidarity aspects of the broad spectrum of social provision have been greatly eroded during the past three decades (Featherstone et al. 2016). 
At the same time, child protection systems across the world meet children and families that have much in common in terms of low education and low income, poor housing, and unemployment or at best insecure employment (Bywaters et al. 2015; Kojan and Fauske 2011). Health problems and especially mental health problems are widespread both for children and their parents. A lot of the children have difficulties at school, often from an early age. The families have restricted, attenuated networks and both children and adults are often poorly socially integrated. Family conflicts, often long-standing, affect relations both within and between generations. For instance, a recent Norwegian study showed that multichallenged families still constitute the largest part of child protection's long-term clientele, comprising around 70 per cent of all families with contact lasting two years or more (Fauske et al. 2009; Clifford et al. 2015). In addition, this has changed very little over time. The socioeconomic status and the difficulties children and parents face are the same; what has changed is that many more families are in contact with child protection. We see a greater gap between the favourable circumstances enjoyed by the majority of families and a minority who are marginalized. This has been a clearly apparent trend in Norway as well as in other countries in recent years.

The challenges child protection families and their children have to face do not seem to have changed much since 1990. Nor is there any evidence of a general improvement in the ways these families manage. The help that child protection provides to improve parental care for children living at home (assistance in the home, advice and guidance, and family preservation evidence-based interventions) is most often given to the least marginalized families. The multi-challenged families, in which the risks of poor care and breakdown of care are greater, seldom receive these forms of help. Children in these families often get help designed to provide better social integration (weekends spent in another family, support for leisure activities etc.) but help that might improve care in their own family is not provided (Clifford et al. 2015). Thus, the risks these children are exposed to will largely remain unmitigated as long as they continue to live at home. Such a state of affairs seems regrettable but in its very nature reflects the freedom to interpret children's and families' life circumstances, and decide how to intervene, 
which helping services at the margin of the market are allowed to do. Helping services within very broad limits are free to decide the terms of service: not even the most rigorous regulation can limit this power, and attempts to regulate it are often bitterly resented.

\subsection{Individualization of Social Needs}

Some researchers conclude that child protection has become rather onesidedly preoccupied with parental competence and responsibility, without adequate attention paid to social and other factors that contribute to deprivation and deficient parental care (Christiansen and Hollekim 2018, Chap. 10 in this book; Featherstone et al. 2016; Lonne et al. 2009; Wastell and White 2017). The focus has shifted from family needs to a widespread tendency to expect that parents must themselves manage the risks for children that arise, however difficult the situation they face. Calder (2016) argues that this shift in focus is associated with a rightsbased approach, reinforcing an already individualized practice and in effect not compensating for the role of the family in maintaining inequality and marginalization, for instance through not being able to offer their children sufficient help and support with their school work and social integration.

Assessing social needs as risk factors might result in a child protection system that operates in a socially discriminating way with too much attention focused upon marginalized families with serious shortfalls in economic and social capital. Consequently, we might see services and professionals operating at an even greater psychological distance from families and the realities of family life in deprived settings. Child protection is mostly concerned with the safety of children and imposes demands that parents must meet to guarantee their safety, and is not much concerned with help that might enable parents to provide better care (Clifford et al. 2015; Featherstone 2016). Social risk factors associated with marginalization become part of an objectifying calculation of risk. This has led, it is claimed, to a less holistic and contextually situated practice (see Christiansen and Hollekim 2018, Chap. 10 of this book). 


\section{The Implementation of CRC in Child Protection}

For analytic purposes, we will draw a distinction between two kinds of rights in the CRC, applying the work of Onora O'Neill (2013, 2016). Protection rights can be viewed as freedom rights, as for example a right to personal security. It is often easy to see who offends against or restricts such freedoms for children. On the other hand, provision rights can be viewed as welfare rights. To understand who has the duty of securing another's rights to welfare, we have to understand the structure of obligations that underpins such rights. The question, as O'Neill puts it, is 'whose obligation?'

\subsection{Freedom Rights and Welfare Rights: Two Sides of the Same Coin}

As pointed out above, children and parents in child protection have to deal with the same challenges and difficulties as they have for decades. Further, we argued that CPS and a broader network of services have not succeeded in meeting the needs of those most marginalized. The question is in what ways implementation of CRC can change this situation.

Professional social work in child protection involves securing both children's freedom rights and (to an increasing extent) their welfare rights. Traditionally the question of whether child protection should intervene has been a matter of making children safe, ensuring that they are not exposed to grossly deficient care, neglect, violence or sexual abuse. Child welfare has had the task of preventing actions or gross omissions (usually by the child's parents) that may threaten his or her integrity or development, or represent an immediate threat or a potential for injury in the future. The current framing of child protection is still primarily concerned with protecting children, and lacks a clear focus on social suffering among the families (Featherstone et al. 2016).

However, dealing with welfare issues that affect children and their families should be a central concern for child protection and other helping services for children and families. Inequality strongly correlates with 
child protection interventions (Bywaters et al. 2015), and might be considered a risk factor for child abuse and neglect. In Norway, for example, protective actions due to deficient care, neglect, violence or sexual abuse have occurred in a stable proportion of child protection cases during the last three decades (Statistics Norway 2015). So these problems cannot account for the greatly increased numbers of children and families who receive assistance or intervention from CPS that we have seen since the mid-1990s.

In practice, it can be quite difficult always to draw robust distinctions between protection rights and welfare rights in child protection. At an empirical level we can see that child protection to an increasing extent intervenes in families, not because there is evidence that parents actively injure their children (Clifford et al. 2015) and by so doing deprive them of their freedom rights. Child welfare protection tends to be increasingly concerned that someone should actively work for and support a child's development. Nowadays, however, these trends are attended by a good deal of confusion. We can encounter statements that equate nonfulfilment of children's welfare rights with active deprivation of rights on the part of parents. There is a tendency to move from claims of preventability (that is the notion that children run developmental risks) to a preventive imperative (the notion that developmental risks warrant intervention if the family is unable to eliminate them).

\subsection{Active Investment in Children}

The striking growth in intervention rates in child protection might be seen as a consequence of social changes that affect families in a society promoting a public health approach in most welfare services, including child protection. Child protection has moved forward into a broader mandate and its development reflects social policies focusing on social investments in children. In this context child protection may have changed its reference from saving children from harm and serious abuse (protection) to concern about 'failing' lives and lifestyles (welfare).

Wyn and White (1997) described trends in western societies that have led to much greater attention being paid to children's functioning in 
school, their mental health, and problems that may indicate family difficulties or care deficits. The underlying trend is the emergence of the knowledge economy and the demands this makes with respect to child development, socialization and education. CPS are no longer only concerned with child abuse and neglect or children with serious behavioural problems. The services have been drawn into the orbit of the educational and health and welfare services where early intervention to secure optimal development and educational attainment for children with difficulties has become a major trend in policy (Stang 2007).

This turn toward active investment in children and a focus on welfare rights has profoundly affected child protection, not least seen in terms of expectations directed at the service, a multiplication of its tasks, and competing priorities within child protection's overall remit (Munro 2011). Scientific progress in the welfare disciplines (medicine, psychology, psychiatry, social work, education) nowadays pulls child protection in different directions, at the same time that we see that the service's horizon (in terms of research and practice developments) becomes ever broader.

\section{Can the Implementation of CRC in Professional Child Protection Work Improve the Lives of the Most Marginalized Children and Families?}

How might the CRC be applied to deal with the many deprivations and inequalities, spoiled life chances and disadvantages suffered by children in child protection? The answer is not too clear, and the question concerns what a broad range of services, and not only the CPS system, should offer to marginalized children and families. CRC contains various articles concerning children's welfare rights and the responsibility of the state in supporting parents' efforts to secure such rights: Articles 26 (social security), 27 (adequate standard of living), 28, 29 (right to education) and 31 (leisure, play and culture).

There is certainly no magic formula for how child protection can deal with the types of marginalization that children and parents struggle with. 
A first step, however, is to realize that marginalization, leading to concrete obstacles when it comes to fulfilling all these rights properly, is a relevant issue for the challenges faced by parents and children in contact with child protection on an everyday basis. Social workers will have to understand this, and incorporate this understanding in their professional approach to children's situation and the quality of care they receive. Child protection is based both on the freedom rights and the welfare rights which are both embedded in the CRC, as mentioned above. Acknowledging this will provide a more holistic approach to children's and parents' situation. Featherstone (2016) argues that protecting children and promoting their welfare means that professionals need to reframe their approach. They must pay attention to the environments and contexts in which children live; families, school and leisure time.

\section{School: One of the Most Important Generators of Marginalization}

\subsection{Education in the Knowledge Society}

Poor educational attainment is often seen as a potential generator for marginalization, creating a foundation for exclusion from the labour market, and poor health and social problems in the knowledge economy (Frønes and Strømme 2010; Vinnerljung et al. 2010). It is important to examine how children in contact with child protection manage at school, the more so because they so often face serious challenges in other respects, such as family, health, social networks and integration. It is well documented that these children, whether living at home or after placement, have difficulties associated with completing schooling at all levels (Iversen et al. 2010; Forsman and Vinnerljung 2012; Skilbred and Iversen 2014; Dæhlen 2015; Valset 2014; Madsen and Backe-Hansen 2015). Official statistics also show that some children in contact with child protection need more time to complete their education (Backe-Hansen et al. 2014). Needless to say, this is a matter of considerable concern, since uncompleted education, and at whatever level, has a negative effect upon life chances. Young adults formerly in contact with child protection are over- 
represented among the unemployed, and receive social security and income support much more frequently than their peers (Clausen and Kristofersen 2008; Backe-Hansen et al. 2014).

Parents in contact with child protection have very often themselves had challenges at school, and many will not have completed secondary or even primary school (Clifford et al. 2015; Fauske et al. 2009). Their children often have a family background with poor network potential vis-à-vis employment and employers, or a lack of bridging social capital (Kojan and Fauske 2011). As well, they are much more likely than their peers to drop out of schooling or employment, and to a greater extent risk long-term dependence on social assistance. Research on non-completion of schooling at upper secondary level has shown that social factors, poor networks and mental health difficulties exert a clear negative effect, hindering completion of schooling and access to the labour market for many (Thrana et al. 2009). Of course, drop-out at upper secondary level is no absolute barrier to employment, but we have to recognize that many child protection children lack the network facilitation and support that could compensate for lack of formal qualifications. For instance, Collin-Hansen (2008) discussed how the development of CPS has led to changes in how responsibility for children's education is perceived. The school is expected to support upbringing and socialization on the part of the family. Parents are expected to support the aims and approaches of the educational system. If some parents are tacitly excluded from this community of interest, this will only serve to reproduce and reinforce marginalization.

\subsection{How Can the CRC Guide Professional Practice in Meeting the Needs of Marginalized Children's' Situation in School?}

Education is an example of how marginalization moves across sectors within state systems, and child protection must recognize these traits. However, child protection plays an ambiguous role in respect of children's education. This is especially evident in the case of the many children who receive various forms of help while living at home (Collin-Hansen 
2008; Kojan and Thrana 2017). Marginalization affects family life at an everyday level and impacts upon children's daily lives. In practical terms (and in the theoretical terms provided by O'Neill) the first question is always that of who is obligated to secure welfare rights. The principle that parents are obligated to manage situations to secure welfare rights for their children is all well and good. But can marginalized parents reasonably be expected to provide adequate support and help for their children in school, particularly if the children have various learning problems? How can the CRC guide professional CPS practice in meeting the needs of marginalized children's situation in school? Article 28 of the CRC states that 'States Parties recognize the right of the child to education, and with a view to achieving this right progressively and on the basis of equal opportunity.' This right concerns primary education, and also requires that different forms of secondary and higher education are available and accessible to every child according to their capacity.

Below we delineate four areas that are relevant in the sense that they can indicate what roles child protection might have in following children up at school, and in securing the rights of CPS children to access to education on a basis of equal opportunity. These recommendations are based on findings from an innovation study dealing with CPS children living at home (Kojan and Thrana 2017). Ten children in contact with CPS were followed for a school year.

\subsection{Child Protection Workers Need Knowledge of Children's Situation at School}

The study showed that CPS professionals had scant knowledge of children's situation in school. There was a one-sided approach focused on the home and family, and child protection's understanding of the children's lives was incomplete and, contextually speaking, quite deficient. Child protection risked putting too much emphasis on parents as the source of children's difficulties. To deal with the complexity of marginalizing factors affecting children, it seems important that child protection adopts a broad theoretical base in its inquiries about how children are cared for. Children's needs are to be understood as something broader than only 
being a matter of relationships within the family. That is after all the import of the shift toward an overlapping and sharing of responsibility for upbringing and socialization, as described by Collin-Hansen (2008). School seen as a social setting is important for children. They spend much of their time there, and an appreciation of their school situation ought to be part of any child protection investigation.

This does not (and this is an important point) mean that CPS should collect information directly from school in all investigations. CPS should set out to tell a different story (Featherstone et al. 2016). Implementing Article 28 requires an exploration of the school setting for the particular child. Child and parents should be asked about this. How does the child manage in particular subjects? Does she or he enjoy school, or not? What does he or she do in breaks between lessons? Who does he or she play with? Has he or she been excluded or bullied? How do parents see their contact with the school? Are they satisfied?

\subsection{Child Protection Workers Can Take the Initiative in Defining Responsibilities}

The boundaries between school and child protection are not clear in practice. The professionals involved can devote a lot of time to obtaining a shared understanding of how supports and intervention are to be framed and organized (Kojan and Thrana 2017). But we need an effective and operationally useful approach to sharing and assigning responsibility when children meet academic and social challenges at school. Children do not have the time to wait for the resolution of professional dilemmas, and they pay a price when things do not work properly and practical arrangements are not in place. CPS has of course an especially important responsibility in securing appropriate schooling for children in care. But the children living at home who are seen to be at risk need help too. Their parents often need support in their contact with school.

Parents with the most complex problems often wanted CPS to involve itself more (Clifford et al. 2015). One major consideration here is that most parents are very concerned and worried about their children, and they often feel unable to deal with the children's difficulties. They feel 
that child protection is actually committed to the child's best interests, even though they experience many setbacks and disappointments in their relations with the service. Parents in CPS are very often alarmed and anxious and feel unable to help their children. They trust child protection, if not to the bitter end, at least through long trials and tribulations. Some of them do not trust school and health services, these being seen as difficult to relate to, and likely to discriminate against their children. Parents see child protection as a partner in the sense that persuasion and negotiation are possible even if time-consuming and frustrating. They are acutely conscious of social difficulties and problems their children may encounter at school, and correspondingly preoccupied with the social advantages that can be gained by children through appropriate help. An expectation of fairness is the guiding principle for parents' efforts on behalf of their child, that she or he should have a chance, and not be excluded or discriminated, and as far as possible treated like other children. However, rights to help are not part of parents' perception of the service; as they see it everything has to be negotiated and struggled for (Clifford et al. 2015).

\subsection{More Help Directed at the School Situation of CPS Children Living at Home}

In Norway, CPS provide relatively few measures aimed at improving children's situation at school (Statistics Norway 2017). Out of 83,970 measures provided by CPS in 2016, only 536 were designed to enhance the child's development relating to education or employment. These numbers illustrate that measures in school are not the main domain of child protection. However, child protection does provide services for some children in cooperation with school, which are not shown in the child protection statistics.

Nevertheless, a review of the literature (Seeberg et al. 2013) shows that some academic approaches can help children in their social adjustment in school, and so enhance the likelihood of them completing their schooling. As we have shown above, children and families in CPS, especially the long-term clientele, have complex difficulties that reflect marginalization 
in a variety of arenas. On the one hand, this might imply a complexity of services, supports and interventions. On the other hand, this might lead to too elaborate and complex services, which could be avoided by using simpler devices, such as tutoring, mentoring, homework assistance and shared diary for school and home. Child protection does not need to be responsible for such forms of help, but should be more aware of children's situation at school and an initiator of practical and useful supports and interventions that can help children at school, whatever complex problems there may be that also involve the home. We need more knowledge about how CPS experience their own responsibilities to implement children's rights to education.

\subsection{Recognize that Children in CPS Have Ability and Potential}

A challenge associated with child protection's interest in the education of CPS children is that there have been persistently negative views about these children's capacities and abilities (Bufdir 2014). Article 28 in CRC uses the term capacity. An important aspect of professional work here is to acknowledge that CPS children have the same capacity to complete their education as other children, given real equality of opportunity. Vinnerljung and Hjern (2011) found that poor school performance among children placed outside the family was not due to weaker cognitive capacity than the child population as a whole, but rather school difficulties related to working memory. This can be related to burdens and anxieties that prevail when child-rearing is plagued by uncertainty and unpredictability.

\section{Conclusion}

A series of studies from many countries and over time has shown the extent of marginalization among child protection families. The question that has to be asked is, Who is responsible for this marginalization? Have parents denied children their rights because they have insecure employment, are 
without higher education and training, or as immigrants have not acquired cultural and linguistic competence? Or are there political constraints? Do we in effect deny children their rights because a reasonable distribution of goods and opportunities in society has not been arranged? O'Neill maintains that it is impossible to decide who has denied subjects their welfare rights unless there is a clearly established obligation for someone to see that the rights are observed. The question of rights is a matter of social order and duty, a social issue.

Our argument here has been that child protection services that examines the child's situation in school will have a better insight into what the child and its parents might need in the form of support and intervention. There will be a better grasp of the child's situation and a better chance of working with family and child. Of course, this will not always be easy. In such work, responsibilities have to be defined and assigned early on. Expectations relating to what other agencies might provide have to be adjusted to realities at the local level. If Article 28 in the CRC is to be taken seriously in child protection, the traditional boundaries whereby child protection is assigned what pertains to the home and family, while schooling remains 'the school's business', will have to be challenged to a much greater extent than we see today. At the same time we have pointed out that increased attention paid to children's situation in school will not in itself enable us to deal with complex problems related to marginalization. In some sense, the right to education is an approach that individualizes social problems, without enough attention paid to the societal causes of marginalization. In contemporary social policies there is a strong emphasis on education or work as a solution to socio-economic marginalization; everyone can have a share in society if their individual agency is improved (Davies 2015).

A stronger emphasis on rights will not necessarily lead to better child protection for children and families who suffer the most complex problems. The rights discourse can also reinforce and reproduce an already individualized, privatized responsibility for children's development, transferring obligations from the state to marginalized parents. This leads to a rights paradox: to secure welfare and development for children, marginalized parents are blamed. This can, or perhaps already does, create an ethos in which the importance of social conditions in shaping family problems and need for welfare is downplayed. 
In a broader perspective, we have to ask whether a more trenchant rights-based approach would improve equality of opportunity for children in CPS. There is of course a danger that only rhetoric will change without any progress on the vital issue of who is obligated to help marginalized children and families. Nevertheless, CRC might help us to rethink the role of child protection in taking the welfare needs of children and families seriously, for example in relation to the situation of the child in school.

\section{References}

Backe-Hansen, E., Madsen, C., Kristoffersen, L. B. \& Hvinden, B. (2014). Barnevern i Norge 1990-2010. En longitudinell studie. NOVA Rapport 9/14. Oslo: NOVA.

Bufdir. (2014). Skolerapport. Hvordan bedre skoleresultatene og utdanningssituasjonen for barn og unge i barnevernet. Oslo: Bufdir.

Bywaters, P., Brady, G., Sparks, T., Bos, E., Bunting, L., Daniel, B., Featherstone, B., Morris, K., \& Scourfield, J. (2015). Exploring inequities in child welfare and child protection services: Explaining the inverse intervention law. Children and Youth Services, 57, 98-105.

Calder, G. (2016). How inequality runs in families. Bristol: Policy Press.

Clausen, S.-E., \& Kristofersen, L. B. (2008). Barnevernsklienter i Norge 1990-2005: en longitudinell studie. Oslo: NOVA.

Clifford, G., Fauske, H., Lichtwarck, W., \& Marthinsen, E. (2015). Minst hjelp til de som trenger det mest? NF-rapport 6. Bodø: Nordlandsforskning.

Collin-Hansen, R. (2008). Barnets rett til opplaring og til vern mot marginalisering i skolen. PhD dissertation. Bergen: University of Bergen.

Dæhlen, M. (2015). School performance and completion of upper secondary school in the child welfare population in Norway. Nordic Social Work Research, 5, 244-261. https://doi.org/10.1080/2156857X.2015.104201.

Davies, W. (2015). The happiness industry: How the government and big business sold us well-being. London: Verso.

Fauske, H., Clifford, G., Lichtwarck, W., Marthinsen, E., Kojan, B. H., \& Willumsen, E. (2009). Det Nye barnevernet: et forsknings- og utviklingsprosjekt $i$ Barnevernet. Barnevernet på ny kurs? Sluttrapport fase 1. Bodø: Nordlandsforskning.

Featherstone, B. (2016). Telling different stories about poverty, inequality, child abuse and neglect. Families, Relationships and Societies, 5, 147-153. https:// doi.org/10.1332/204674316X14540714620085. 
Featherstone, B., White, S., \& Morris, K. (2016). Re-imagining child protection: Towards humane social work with families. Bristol: Policy Press.

Forsman, H., \& Vinnerljung, B. (2012). Interventions aiming to improve school achievements of children in out-of-home care: A scoping review. Children and Youth Services Review, 34, 1084-1091.

Frønes, I., \& Strömme, H. (2010). Risiko og marginalisering. Oslo: Gyldendal. Hennum, N. (2017). The Norwegian child protection services in stormy weather. Critical and radical social work. An international journal, 5(3), 319-334. https://doi.org/10.1332/204986017X15029695863676.

Iversen, A. C., Hetland, H., Havik, T., \& Stormark, K. M. (2010). Learning difficulties and academic competence among children in contact with the child welfare system. Child \& Family Social Work, 15(3), 307-314. https:// doi.org/10.1111/j.13652-206.2009.00672.x.

Kojan, B. H. (2011). Klasseblikk på et barnevern i vekst. PhD dissertation. Trondheim: NTNU.

Kojan, B. H., \& Fauske, H. (2011). Et klasseperspektiv på barnevernets familier. Tidsskrift for velferdsforskning, 14(2), 95-109.

Kojan, B. H., \& Thrana, H. M. (2017). Aktiv støtte til hjemmeboende barnevernsbarn i skolen. Trondheim: NTNU, Institutt for sosialt arbeid.

Lonne, B., Parton, N., Thompson, J., \& Harries, M. (2009). Reforming child protection. Oxon.: Routledge.

Madsen, C., \& Backe-Hansen, E. (2015). Barn og unge som mottok hjelpetiltak 1993-2010. In Ø. Christiansen et al. (Eds.), Forskningskunnskap om barnevernets hjelpetiltak. Bergen: Uni Research Helse, RKBU Vest.

Munroe, E. (2011). Munro review of child protection: Final report. London: DfE.

O’Neill, O. (2013). Session 4-Reason and evidence in ethics. Science, reasons and normativity. European Review, 21, 94-99.

O’Neill, O. (2016). Justice across boundaries. Whose obligations? Cambridge: Cambridge University Press.

Pusic, E. (1972). Social welfare and social development. Berlin: Walter de Gruyter \& Co.

Seeberg, M. L., Winsvold, A., \& Sverdrup, S. (2013). Skoleresultater og utdanningssituasjon for barn i barnevernet. En kunnskapsoversikt. Oslo: NOVA.

Skilbred, D., \& Iversen, A. C. (2014). Unge voksne som har bodd i fosterhjem og tatt høyere utdanning: Suksessfaktorer? Norges Barnevern, 4, 161-176.

Stang, E. G. (2007). Det er barnets sak. Barnets rettsstilling i sak om hjelpetiltak etter barnevernloven \$ 4-4. Oslo: Universitetsforlaget.

Statistics Norway. (2015). Tabell 1. Meldingar til barnevernet, etter konklusjon, innhald $i$ meldinga, kven som melde saka og alder. Statistikkbanken. Oslo: SSB. 
Statistics Norway. (2017). Measures from the child welfare services per 31 December, by measure. Retrieved 21 February 2018 from http://www.ssb.no/en/sosialeforhold-og-kriminalitet/statistikker/barneverng/aar

Thrana, H. M., Anvik, C., Bliksvær, T., \& Handegård, T. L. (2009). Hverdagsliv og drømmer: for unge som står utenfor arbeid og skole. Bodø: Nordlandsforskning. Valset, K. (2014). Ungdom utsatt for omsorgssvikt—hvordan presterer de på skolen? In E. Backe-Hansen, C. Madsen, L. B. Kristoffersen, \& B. Hvinden (Eds.), Barnevern i Norge 1990-2010. En longitudinell studie (pp. 127-155). Oslo: NOVA.

Vinnerljung, B., Berlin, M., \& Hjern, A. (2010). Skolbetyg, utbildning og risker for ogynnsam utveckling hos barn. In Socialstyrelsen Social Rapport (pp. 227-276). Stockholm: Socialstyrelsen.

Vinnerljung, B., \& Hjern, A. (2011). Cognitive, educational and self-support outcomes of long-term foster care versus adoption. A Swedish national cohort study. Children and Youth Services Review, 33, 1902-1910.

Wastell, D., \& White, S. (2017). Blinded by science. The social implications of epigenetics and neuroscience. Bristol: Policy Press.

Wyn, J., \& White, R. (1997). Rethinking youth. London: SAGE Publications.

Open Access This chapter is licensed under the terms of the Creative Commons Attribution 4.0 International License (http://creativecommons.org/licenses/ by/4.0/), which permits use, sharing, adaptation, distribution and reproduction in any medium or format, as long as you give appropriate credit to the original author(s) and the source, provide a link to the Creative Commons license and indicate if changes were made.

The images or other third party material in this chapter are included in the chapter's Creative Commons license, unless indicated otherwise in a credit line to the material. If material is not included in the chapter's Creative Commons license and your intended use is not permitted by statutory regulation or exceeds the permitted use, you will need to obtain permission directly from the copyright holder.

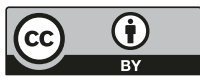

